\title{
Use of Spruce Plantations by Snowshoe Hare in New Brunswick
}

\author{
by
}

\author{
G.R. Parker ${ }^{1}$
}

\begin{abstract}
Spruce plantations in New Brunswick were examined for seasonal use by snowshoe hares (Lepus americanus). Summer live capture frequencies of adults and winter pellet densities served as indices of summer and winter use, respectively. Hares preferred plantations 11-16 years old both winter and summer. Winter use was correlated with the use (food) of deciduous tree and shrub twigs $\leq 2 \mathrm{~m}$ high and the availability (cover) and use (food) of conifer twigs $\leq 2 \mathrm{~m}$ high. Summer use was correlated with the availability (cover) of conifer twigs only. Hare densities were lowest in plantations supporting spruce twig densities $\leq 30 / \mathrm{m}^{2}$ and highest where densities $>120 / \mathrm{m}^{2}$. Deciduous twigs were browsed more intensively than conifer twigs. Elimination of potential cover (brush, slash, residual scrub conifer) should reduce damage to young spruce from hare browsing during the first few years after planting.
\end{abstract}

Key words: Spruce plantations, snowshoe hare, New Brunswick, silvicultural management, forestry, animal damage.

\section{Résumé}

Des plantations d'épinettes au Nouveau-Brunswick ont été étudiées sous l'angle de la fréquentation saisonnière du lièvre d'amérique (Lepus americanus). La fréquence des captures d'adultes vivants, en été, et la densité des crottes, en hiver, ont servi d'indices de fréquentation. Les lièvres ont démontré une préférence pour les plantations de 11 à 16 ans, tant en hiver qu'en été. On a corrélé la fréquentation hivernale avec la consommation de ramilles d'arbres et d'arbrisseaux décidus situées à une hauteur $\leq 2 \mathrm{~m}$, et avec la disponibilité (couvert) et la consommation de ramilles de conifères situées à une hauteur $\leq 2 \mathrm{~m}$. La fréquentation estivale a été corrélée uniquement avec la disponibilité (couvert) des ramilles de conifères. Les densités des lièvres étaient inférieures dans les plantations aux densités de ramilles d'épinette $\leq 30 / \mathrm{m}^{2}$, et étaient supérieures là où les densités étaient $>120 / \mathrm{m}^{2}$. Les ramilles des espèces décidues ont fait l'objet d'un broutage plus intensif que celles des conifères. L'élimination de couverts potentiels (broussailles, rémanents, petits conifères résiduels) devrait réduire les dommages causés aux jeunes épinettes par le broutage des lièvres au cours des toutes premières années suivant la plantation.

\section{Introduction}

The mixed Acadian Forest of Atlantic Canada has experienced dramatic change because of demands from an expanding wood fibre industry. That change has accelerated over the past several decades with increased mechanical means for harvesting, an expanding pulp and paper industry and intensive forest management programs. Conifer species, especially balsam fir (Abies balsamea) and red spruce (Picea rubra) have replaced climax deciduous species such as yellow birch (Betula alleghaniensis), sugar maple (Acer saccharum) and beech (Fagus grandifolia). Dominant deciduous species are now often represented by early- and midsuccessional species such as white birch (Betula papyrifera),

1The author is a research scientist with the Canadian Wildlife Service, Sackville,
New Brunswick EOA 3C0. Cooperation of J.D. Irving Ltd. and New Brunswick New Brunswick EOA 3 CO. Cooperation of J.D. Irving Ltd. and
Department of Natural Resources is gratefully acknowledged. grey birch (Betula populifolia), poplar (Populus spp), cherry (Prunus spp) and red maple (Acer rubrum) (Rowe 1972). The demand for wood fibre by the pulp industry has necessitated intensive silvicultural programs directed at reducing the period of cutting rotation. Whereas clearcuts were once left to natural regeneration, cutting rotations may soon be reduced by half through mechanical site preparation, planting of conifer nursery stock and suppression of competitive deciduous species with herbicides.

The increased attention given to intensive forest management in New Brunswick is impressive. The amount of reforestation on Crown and private land has increased from 9700 ha in 1977 to 22000 ha in 1982 . The use of herbicides on plantations increased from 4000 ha in 1977 to 13700 ha in 1982.2

The question then arises as to what impact contemporary forest management practices may have on animal communities. What faunal communities are associated with these 
recent even-aged conifer stands and how do they compare to those associated with early successional mixed forests which would normally develop on sites subjected to forest harvest operations?

In 1981, the Canadian Wildlife Service began studies of animal communities within spruce and pine plantations in New Brunswick. This paper reports on the seasonal distribution of snowshoe hares within spruce plantations. Density indices are examined relative to measured habitat characteristics and management implications are discussed.

\section{Study Area and Methods}

Ten sites were selected for study with the aid of forest cover type maps, aerial photographs and ground checks. In 1981 five sites were examined in southern New Brunswick. In 1982 five additional sites were studied in the northern part of the province. The southern sites were within the Southern Uplands Section of the Acadian Forest Region and the northern sites were within the Temiscouata-Restigouche Section of the Great Lakes-St. Lawrence Forest Region (Rowe 1972). Both sites have close affinities with tolerant hardwoods (sugar maple, beech, and yellow birch) on the well drained upper slopes and hilltops and a mixture of the same species with red maple, white birch, balsam fir, and spruces (Picea spp) on the lowlands. Red spruce in the south is replaced by white $(P$. glauca) and black ( $P$. mariana) spruce in the north. Both regions are characterized by deep humo-ferric podzol soils (Rowe 1972).

Sites sampled included seven spruce plantations aged 2, 7 , $11,12,15,16$ and 17 years and three mature (60 years+) natural spruce-fir stands. All plantations were stocked at 800 trees/ha. Study plots were positioned within each site and varied from 7.0 to 12.2 ha depending upon size and configuration of the stand. With the use of compass and measuring tape, a grid of $50-\mathrm{m}$ spaced intercepts was marked with flagging. The main grid was used during forest bird surveys. At alternate intercepts, vegetation was measured within a $1 \times 10 \mathrm{~m}$ plot. Hare pellets were counted within a $1-m^{2}$ subplot. Winter pellets were identified by their light colour and surficial position on the ground debris. All twigs (lateral and terminal branches) $\leqslant 5 \mathrm{~cm}$ long and $\leqslant 2 \mathrm{~m}$ above ground were counted by tree and shrub species within a $1 \times 5 \mathrm{~m}$ subplot and recorded as browsed (hare or ungulate) or unbrowsed. The percentage ground cover (occular estimation) of brush, slash and ground vegetation was also recorded within the $5-m^{2}$ subplot. Vegetation measurements recorded within the $10-\mathrm{m}^{2}$ plot included the stem diameters and heights of deciduous and conifer trees and ground cover estimates (occular estimation) for foliage $\leqslant m$ high.

Snowshoe hares were live-trapped at $25-\mathrm{m}$ spaced intercepts. The live-capture plot measured $175 \mathrm{~m} \times 175 \mathrm{~m}$ ( $3 \mathrm{ha}$ ) and was positioned within the larger study plot. One doubledoor Tomahawk livetrap (Tomahawk Live Trap Co., Tomahawk, Wisconsin) was positioned at each of the 64 intercepts for eight consecutive trap nights. Each plot was live-trapped once during the summer period. Traps were baited with apples and tended each morning. Captured hares were ear-tagged (monel metal eartags \#3, National Band and Tag Co., Newport, Kentucky) and released. Only adult hare first captures were used for comparative density indices to avoid bias created by recruitment of juveniles throughout the summer.

\section{Results and Discussion}

Habitat Selection. The distribution of hares during the summer live-capture program showed hares to be most abundant within plantations 11-16 years of age (Fig. 1). The distribution of live-capture frequencies among plantations

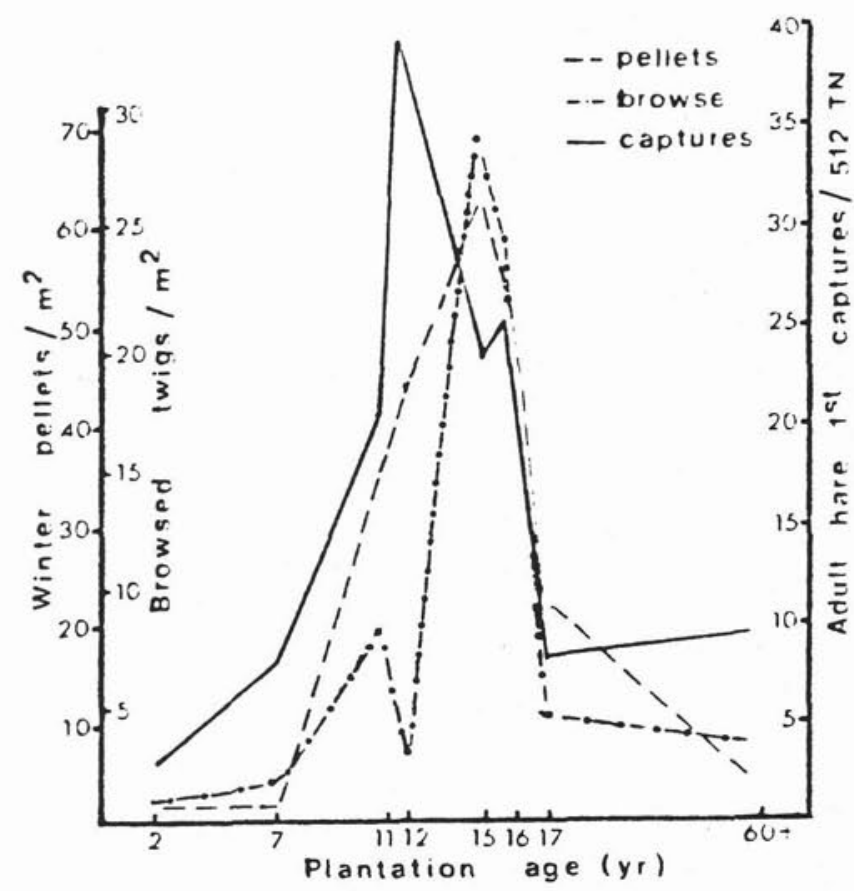

Figure 1. The distribution of winter pellets, browsed twigs and summer live captures of hares among spruce plantations sampled in New Brunswick.

was non-random $\left(x^{2}=63.7 ; d f=6 ; p<0.001\right)$; contributions to the $x^{2}$ variate were greatest for the youngest age class (negative selection: $x^{2}=11.82 ; p<0.001$ ) and the 12-yr-old plantation (positive selection: $x^{2}=29.8 ; p<0.001$ ).

The use of pellet counts to evaluate habitat use by hares has been used successfully by Adams (1959), Bookhout (1965), MacLulich (1937) and Orr and Dodds (1982). In this study the densities of pellets within plantations in early spring are considered comparative indices of winter use. The distribution of pellets among plantations was non-random $\left(x^{2}=162.9 ; d f=6 ; p<0.005\right) ;$ contributions to the $x^{2}$ variate were greatest for the youngest $(2-7-y r$ : negative selection: $\mathrm{x}^{2}>27.6<28.4 ; \mathrm{df}=6 ; \mathrm{p}<0.005$ ) and 15-16-yr (positive selection: $\left.x^{2}>30.5<41.5 ; \quad d f=6 ; p<0.005\right)$ plantations (Fig. 1). There was a significant positive correlation $(r=0.79$; $\mathrm{df}=6 ; \mathrm{t}=3.17 ; \mathrm{p}<0.02$ ) between hare live-capture frequencies and pellet densities. I show later, however, that pellet densities is a better index to winter hare distribution than summer live-capture frequencies.

The third measurement of plantation use by hares was the amount of browsing, i.e. number of available $(\leqslant 2 \mathrm{~m}$ above ground) twigs browsed. The distribution of browsed twigs among plantations followed that for live-captures and pellet densities (Fig. 1). All three indices of habitat use show a preference by hares for plantations 11-16 years old. Hares selected against the very young plantations and mature spruce-fir forest.

Browse Availability and Use. Total available forage peaked in plantations $10-15$ years of age (Fig. 2). In the youngest plantations, spruce seedlings contributed only marginally to the total available woody food supply. The sucker growth of deciduous trees (e.g. maples and birches), various shrubs and raspberries comprised most of the available browse. By seven years after planting, spruce contributed $45 \%$ to the total available twigs. The proportion increased to $49 \%, 88 \%$, and $91 \%$ for plantations aged 11,12 and 15 years, respectively. Total 


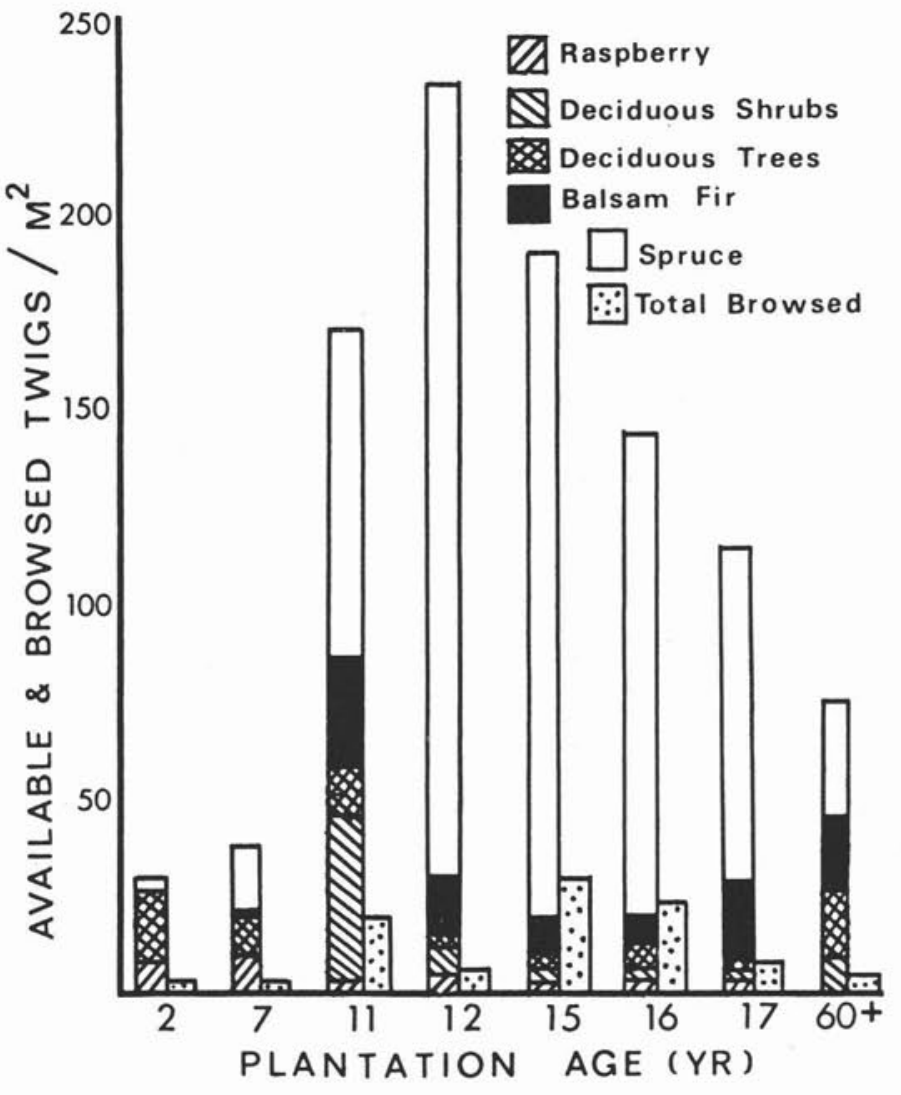

Figure 2. The relative abundance of available twigs $(1 / 45 \mathrm{~cm}$ long: $1 / 22 \mathrm{~m}$ above ground) among spruce plantations sampled in New Brunswick. available twigs, and the contribution to that total by spruce, declined from 16 years to maturity.

Snowshoe hares showed a preference for deciduous twigs as browse $\left(x^{2}=55.91 ; d f=6 ; p<0.005\right)$. Twigs of conifers were browsed relative to their availability $\left(x^{2}=9.26\right.$; $d f=6$; $p>0.05)$. For all sites sampled, the proportions of available twigs browsed for deciduous trees, shrubs, raspberry, spruce and fir were $26 \%, 25 \%, 9 \%, 7 \%$ and $6 \%$, respectively. The preference for non-conifer forage as browse by hares is illustrated in Fig. 3. Deciduous trees, shrubs and raspberry contributed only $7 \%$ and $34 \%$ of available twigs in the $17-y r$-old plantation and mature spruce-fir stands, respectively, but represented $58 \%$ and $84 \%$ of the total twigs browsed.

Browse use (\% available twigs browsed) within the deciduous tree species class, for all sites sampled, was: Acer spicatum - 81\%; Acer saccarhum - 75\%; Salix spp - 44\%; Acer rubrum - 40\%; Betula papyrifera - 19\%; Betula lutea - 12\%; Populus spp $-11 \%$. Within the deciduous shrub class, the more important species were Diervilla Ionicera (42\%), Lonicera canadensis (34\%), Viburnum alnifolium (33\%), V. cassinoides (27\%), Sambucus spp (29\%) and Vaccinium spp (29\%).

Relationships Between Habitat and Use. Linear correlation analyses were applied to indices of use (i.e. adult hare first captures; pellet densities) and the availability and use of conifer, deciduous tree and shrub forage (Table 1). Adult hare first captures in summer were significantly related to the availability of deciduous (negative) and conifer (positive) twigs only. Pellet densities were significantly related to the availability of conifer twigs, the number of conifer twigs browsed and
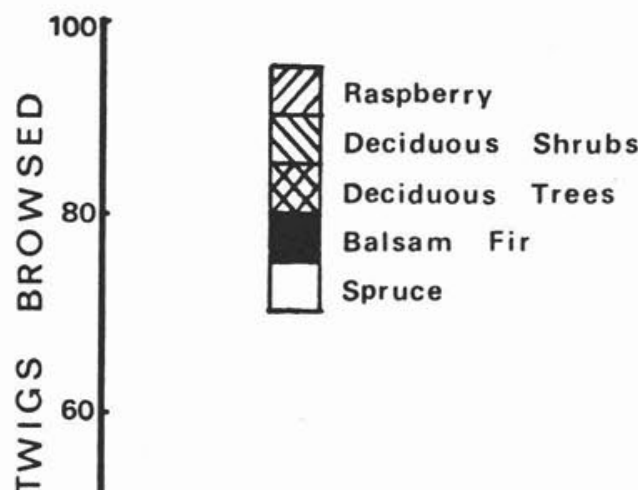
Table 1. Correlation coefficient values from linear regression analysis between indices of hare abundance and the availability and use of forage within spruce plantations in New Brunswick.

\begin{tabular}{lcc}
\hline & \multicolumn{2}{c}{ Hare abundance indices } \\
\cline { 2 - 3 } $\begin{array}{c}\text { Forage availability } \\
\text { and use }\end{array}$ & $\begin{array}{c}\text { Adult hare } \\
\text { 1st capture } \\
\text { (summer) }\end{array}$ & $\begin{array}{c}\text { Pellet densities } \\
\mathbf{( ~}^{\mathbf{2}} \mathbf{)} \\
\text { (winter) }^{\text {(sum }}\end{array}$ \\
\hline $\begin{array}{l}\text { Twig availability } \\
\text { Deciduous }\end{array}$ & $-0.70^{*}$ & -0.67 \\
Conifer & $0.90^{* * *}$ & $0.88^{* *}$ \\
Shrubs & 0.22 & 0.15 \\
Twig use (no. browsed) & & \\
Deciduous & 0.15 & 0.59 \\
Conifer & 0.43 & $0.84^{* *}$ \\
Shrubs & 0.33 & 0.24 \\
Twig use (\% browsed) & & \\
Deciduous & 0.36 & $0.79^{*}$ \\
Conifer & 0.37 & $0.77^{*}$ \\
Shrubs & 0.67 & $0.76^{*}$ \\
\hline
\end{tabular}

* $p<0.05$

${ }^{* *} p<0.01$

$* * *<<0.005$

the proportion of conifer, deciduous and shrub twigs browsed. All correlations were positive except between pellet densities and the availability of deciduous twigs. Significant correlations between pellet densities and use of browse in winter confirms the earlier assumption that it is the best index of winter habitat use by hares. The live captures of adult hares show timespecific summer distributions only.

Other measured habitat variables were tested for significant correlations with summer and winter hare abundance indices. Those habitat variables were: the percentage ground cover of shrub and deciduous and conifer tree foliage $\leqslant 2 \mathrm{~m}$ above ground; the percentage ground cover of brush and slash, grasses and sedges, forbs and raspberry; the mean conifer and deciduous tree stem diameters for trees $>2 \mathrm{~m}$ high; the mean height of conifer and deciduous trees $>2 \mathrm{~m}$ high; and the mean density (stems/ha) of deciduous and conifer tres $\leqslant 2 \mathrm{~m}$ high and $>2 \mathrm{~m}$ high. All tests of correlation were not significant.

Although hares preferred deciduous twigs as browse, correlations between summer and winter hare abundance indices and availability of deciduous twigs were negative, significantly so in summer. The correlation between abundance of deciduous twigs and conifer twigs is also negative and significant $(r=-0.81 ; t=-3.32 ; d f=6 ; p<0.02)$. The relationship between hare abundance and spruce cover is positive and highly significant in both winter $(p<0.01)$ and summer $(p<0.005)$. These analyses show that although in young plantations deciduous twig densities reach maximum values, conifer twigs are at minimum values. As plantations get older, deciduous values decline and conifer values increase, at least through the first 12-15 years. The lack of conifer cover in young plantations and the dependency of hares upon that habitat variable reduces the use of those sites by hares although available preferred food reaches maximum values. The linear relationship of deciduous browse and conifer cover with summer hare abundance is illustrated in Fig. 4. The distributions of winter pellets and summer live-captures were similar; the dependence upon cover in both summer and winter is apparent. Winter densities. however, reach maximum values in habitat with a generous interspersion of deciduous twigs $\left(5-10 / \mathrm{m}^{2}\right)$ within moderately dense spruce cover (80-180 twigs $\left./ \mathrm{m}^{2}\right)$. The correlation of hare densities with cover agrees with the study by Orr and Dodds (1982) of hare habitat in Nova Scotia.

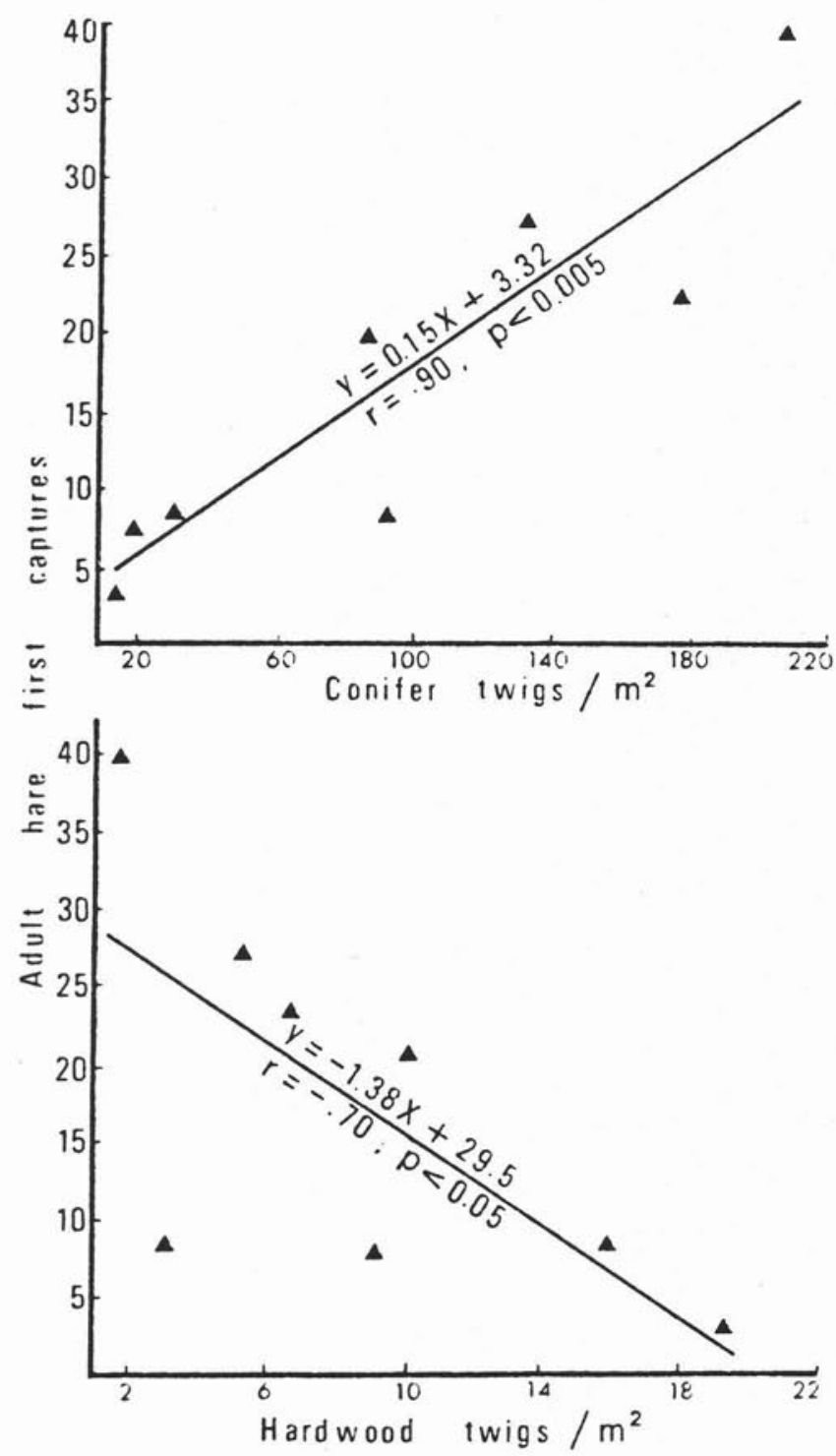

Figure 4. Relationships between availability of conifer and hardwood twigs and summer abundance of snowshoe hares among spruce plantations sampled in New Brunswick.

Management Implications. Spruce plantations in New Brunswick provide excellent habitat for snowshoe hares. The value of plantations to hares in winter is enhanced when deciduous tree and shrub species are available as a preferred source of food. In summer, hares prefer plantations for cover and the availability of deciduous tree and shrub species does not significantly influence densities.

In summer, hare densities are positively correlated only with the availability of conifer twigs $\leqslant 2$ m above ground (cover). In winter, hare densities are also positively related to conifer cover (twig densities), but also to the intensity of browsing upon deciduous tree, shrub and spruce twigs.

In years of exceptionally high hare densities, damage from browsing may occur to terminal and lateral leaders of young stock and from occasional girdling of older stock. Damage to young stock $(<1 \mathrm{~m})$ must occur during the time of nil or low snow coverage. As summer hare densities in plantations were positively related only to the density of conifer twigs $\leqslant 2 \mathrm{~m}$ in height (immediate cover), the absence or reduction of that requirement (i.e. brush, slash, residual conifer trees and 
shrubs) in young plantations should diminish the use of these areas by hares.

On the Cape Breton Highlands, girdling of young trees in overstocked naturally regenerating stands of balsam fir decreased stand volume through retarded growth and death of trees. Damage by hares to individual trees in adjacent open fir stands was minimal and stand volume was not affected (Lloyd-Smith and Piene 1981). That study emphasized the importance of conifer cover to hares in winter, a relationship also documented for other regions in North America (Wolff 1980; Sullivan and Sullivan 1983).

Browsing on conifer twigs in old plantations is seldom damaging to the tree. Browsing of twigs on lower limbs may actually serve as a natural means of pruning and reducing stock competition. High densities of hares in winter in older plantations also serves to reduce the competition between spruce and deciduous tree species. Over $3 / 4$ of the available deciduous twigs had been browsed by hares in plantations supporting the highest densities of hares. Girdling of maple saplings was also common. Such heavy browsing retards deciduous tree growth. The incidence of many dead maple and birch stems with heavy browsing suggests that several successive years of intensive browsing on new twig growth results in the death of the plant. Snowshoe hares can contribute to the pruning of the commercial stock and suppression of deciduous competition in intermediate-aged plantations.

The correlation between hare and conifer twig densities suggests that early thinning and mechanical pruning of the lower limbs ( $\leqslant 2 \mathrm{~m}$ above ground) of spruce stock in intermediate-aged plantations (11-16 years) should lead to decreased use of those areas by snowshoe hares. However, as significant damage to conifer stock in intermediate- and older-aged plantations ( $\geqslant 11$ years; $\geqslant 3 \mathrm{~m}$ high) is negligible, a decrease in hare densities may be pointless.

Control of hares within young plantations may be advisable because of damage from browsing on the terminal and lateral leaders of spruce seedlings. Severe damage may seriously reduce growth of spruce and, in extreme cases, cause tree death and decreased rates of stocking. Removal of potential cover, especially from the peripheral zones, should contribute to decreased use by hares. Current silvicultural practices of site preparation with mechanical tree crushers and application of herbicides serves to eliminate or suppress potential hare cover.

\section{References}

Adams, L. 1959. An analysis of a population of snowshoe hares in northwestern Montana. Ecol. Monogr. 29: 151-170.

Bookhout, T.A. 1965. The snowshoe hare in upper Michigan: Its biology and feeding coactions with white-tailed deer. Mich. Dep. Conserv. Res. and Dev. Rept. 28. 190 p.

Lloyd-Smith, J. and H. Piene. 1981. Snowshoe hare girdling of balsam fir on the Cape Breton Highlands. Can. For. Serv., Marit. For. Res. Cent., Fredericton, NB, Inf. Rept. M-X-124. 8 p.

MacLulich, D.A. 1937. Fluctuations in the numbers of varying hare (Lepus americanus). Univ. of Toronto Studies, Biol. Ser. 43, University of Toronto Press, Toronto, Ont. $136 \mathrm{p}$.

Orr, C.R. and D.J. Dodds. 1982. Snowshoe hare habitat preferences in Nova Scotia spruce-fir forests. Wild. Soc. Bull. 10: 147-150.

Rowe, J.S. 1972. Forest regions of Canada. Can. For. Serv. Publ. No. $1300.172 \mathrm{p}$

Sullivan, T.P. and D.S. Sullivan. 1983. Use of index lines and damage assessments to estimate population densities of snowshoe hares. Can. J. Zool. 61: 163-167.

Wolff, J.O. 1980. The role of habitat patchiness in the population dynamics of snowshoe hares. Ecol. Monogr. 50: 111-130.

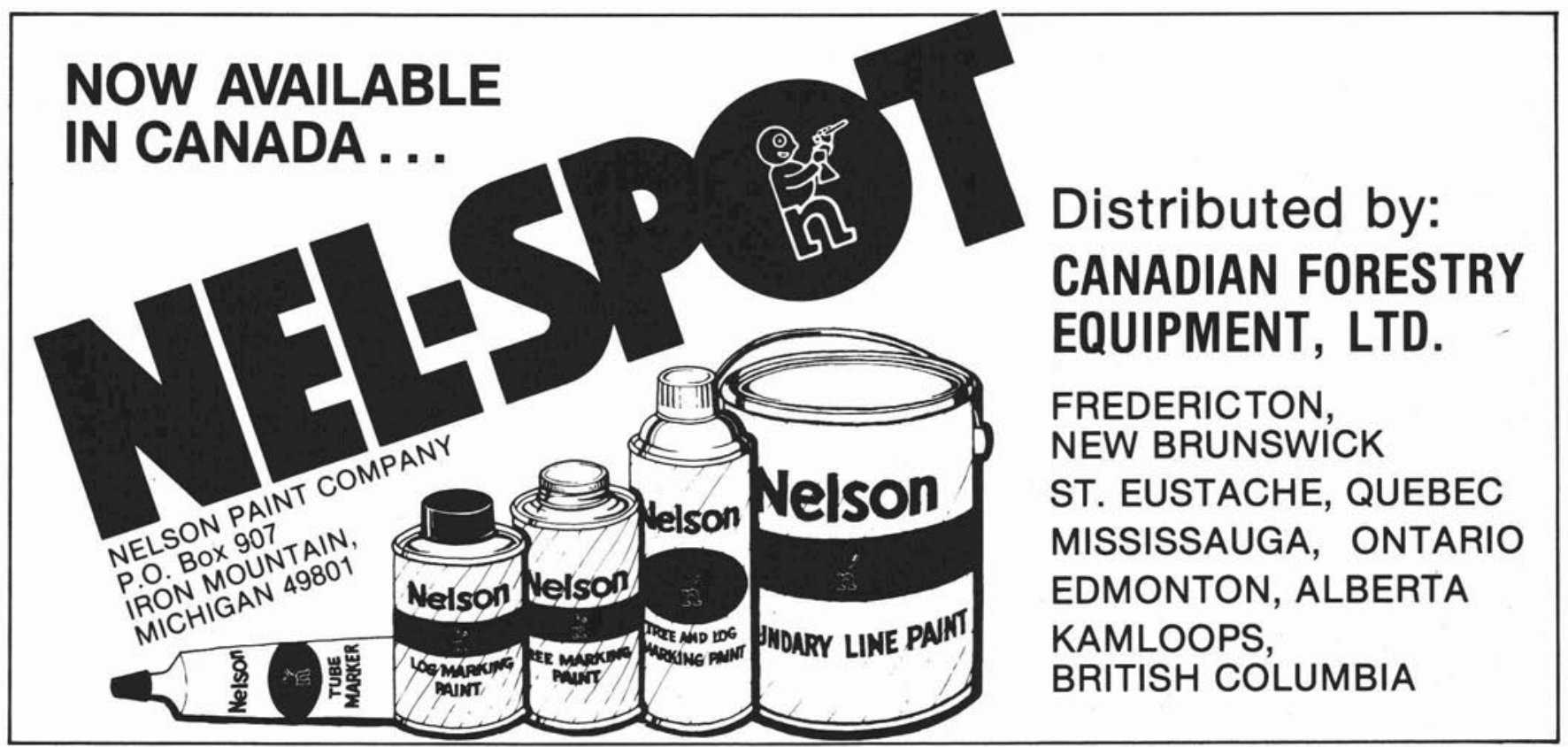

